\title{
Person of the Issue: John Dewey (1859-1952)
}

\section{Ankit Patel*}

\begin{tabular}{|c|c|}
\hline Born & $\begin{array}{l}\text { October } 20,1859 \\
\text { Burlington, Vermont, United States }\end{array}$ \\
\hline Died & $\begin{array}{l}\text { June } 1,1952 \text { (aged 92) } \\
\text { New York, United States }\end{array}$ \\
\hline Alma mater & $\begin{array}{l}\text { University of Vermont, } \\
\text { Johns Hopkins University }\end{array}$ \\
\hline Religion & Western Philosophy \\
\hline Era & 20th-century philosophy \\
\hline School & Pragmatism \\
\hline Main interests & $\begin{array}{l}\text { Philosophy of education, } \\
\text { Epistemology, Journalism, Ethics }\end{array}$ \\
\hline
\end{tabular}

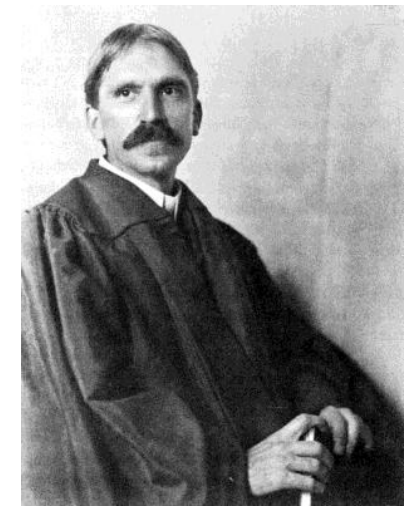

John Dewey (October 20, 1859 - June 1, 1952) was an American philosopher, psychologist, and educational reformer whose ideas have been influential in education and social reform. Dewey is one of the primary figures associated with philosophy of pragmatism and is considered one of the founders of functional psychology. A well-known public intellectual, he was also a major voice of progressive education and liberalism. Although Dewey is known best for his publications about education, he also wrote about many other topics, including epistemology, metaphysics, aesthetics, art, logic, social theory, and ethics.

John Dewey graduated from the University of Vermont and spent three years as a high school teacher in Oil City, Pennsylvania. He then spent a year studying under the guidance of G. Stanley Hall at John Hopkins University in America's first psychology lab. After earning his Ph.D. from John Hopkins, Dewey went on to teach at the University of Michigan for nearly a decade.

In 1894, Dewey accepted a position as the chairman of the department of philosophy, psychology and pedagogy at the University of Chicago. It was at the University of Chicago that Dewey began to formalize his views that would contribute so heavily to the school of thought known as pragmatism. The central tenant of pragmatism is that the value, truth or meaning of an idea lies in its practical consequences. Dewey also helped establish the University of Chicago Laboratory Schools, where he was able to directly his apply his pedagogical theories.

Dewey eventually left the University of Chicago and became a professor of philosophy at Columbia University from 1904 until his retirement in 1930. In 1905, he became President of the American Psychological Association.

*MA, Clinical Psychology, Dept. of Psychology, Sardar Patel University, Vidhyanagar, Gujrat

(C) 2014 A Patel; licensee IJIP. This is an Open Access Research distributed under the terms of the Creative Commons Attribution License (http://creativecommons.org/licenses/by/2.0), which permits unrestricted use, distribution, and reproduction in any Medium, provided the original work is properly cited. 
Dewey's work had a vital influence on psychology, education and philosophy and he is often considered one of the greatest thinkers of the 20th-century. His emphasis on progressive education has contributed greatly to the use of experimentation rather than an authoritarian approach to knowledge. Dewey was also a prolific writer, publishing numerous books and articles on a wide range of subjects including education, art, nature, philosophy, ethics and democracy over his 65-year writing career.

\section{TIME LINE}

1. October 20, 1859 - John Dewey born at 186 South Willard Street, Burlington, Vt. His father, Archibald Sprague, was thriving in the grocer business and his mother Lucina Artemisia Rich was a devote Christian.

2. November 24, 1859 - Charles Darwin publishes On the Origin of the Species. In 1910 Dewey would publish the influential text, Influence of Darwin on Philosophy and Other Essays. New York: Henry Holt and Company (1910).

3. 1865 - Lee surrenders to Grant at Appomattox Court House on April 9, 1865, ending the Civil War. The 13th Amendment ends slavery.

4. 1879 - After studying with H.A.P. Torrey, who mentored Dewey in moral philosophy, Dewey graduates from the University of Vermont, Phi Beta Kappa.

5. 1882 - Journal of Speculative Philosophy published Dewey's first articles; "The Metaphysical Assumptions of Materialism" and "The Pantheism of Spinoza." Dewey decides to make philosophy his life pursuit.

6. 1884 - Dewey graduates with a doctoral degree from John Hopkins University after studying with Charles S. Pierce and George Sylvester Morris.

7. 1884 - Dewey hired as Associate Professor at University of Michigan and works with George Morris on Hegelianism.

8. 1886 - Dewey marries Alice Chipman. Dewey takes the position of the Head of the Philosophy Department at the University of Chicago which included the disciplines of psychology and pedagogy.

9. 1894 Dewey's two and a half year old son Morris dies of diphtheria in Italy.

10. 1897 - Guglielmo Marconi takes the radio, his invention, to the Wireless Telegraph and Signal Company Ltd. in London.

11. 1899 - Dewey elected President of the American Psychological Association and The School and Society, which had been a series of lectures, was published.

12. 1902 - Dewey founds the school of education at the University of Chicago. The University elementary and high schools became known as the Laboratory Schools.

13. 1904 - Dewey leaves Chicago and takes the position of Professor of Philosophy and Lectureship in Psychology at Columbia University.

14. 1910 - William James, one of the great American philosophers of pragmatism, dies.

15. 1904 - Dewey's son Gordon dies at the age of eight of typhoid fever in Ireland.

16. 1912 - Dewey argues that women's suffrage is necessary to complete the democratic movement. Dewey addresses the summer students at Columbia on women's suffrage.

17. 1912 - Emperior P'u Yi steps down from the Dragon Throne of the Manchu's. Doctor Sun Yatsen helps lead the revolution which had begun the year before in Sichuan province.

18. 1914 - Archduke Franz Ferdinand assassinated leading to World War I. 
19. 1915 - Dewey presents a series of lectures for the John Calvin McNair Foundation at the University of North Carolina in February under the title "German Philosophy and Politics."

20. 1918-1919 - Dewey takes a leave from Columbia University and spends the first half of the winter lecturing at the University of California. Dewey then travels with Alice to China and Japan.

21. 1918 - President Wilson announces his famous Fourteen Points to a joint session of Congress on January 8, 1918. His speech laid the groundwork for the end of WWI.

22. 1920 - Dewey lectures at the Imperial University in Tokyo and then at National University in Peking. The Chinese lectures, published in Chinese, are now available in an English: John Dewey: Lectures in China 1919 - 1920.

23. August 18, 1920 - the Nineteenth Amendment is ratified giving women the right to vote.

24. 1924 - Dewey travels to Turkey by the invitation of the Turkish government for educational system reform.

25. 1925 - Experience and Nature published and Dewey's metaphysical philosophy attempts to dissolve past mind/body dualities.

26. 1926 - Alfred Barnes takes Dewey along with a group of students to the museums of Madrid, Paris, and Vienna.

27. July 14, 1927 - Alice Dewey dies in New York City. During her life Alice had profound influence on Dewey's philosophy of education.

28. 1930 - Dewey retires from Columbia and named Professor Emeritus.

29. 1931 - Dewey's infant granddaughter dies. Additionally, George H. Mead dies. Mead and Dewey along with colleagues James H. Tufts, James R. Angell, and Edward Scribner Ames formed the core of the Chicago School of Pragmatism.

30. 1932 - Immigrant Adolf Hitler gains German citizenship. The German physicist Albert Einstein is granted a visa to the United States.

31. 1933 - Dewey works to socialize government programs during the Depression years.

32. 1933 - Franklin D. Roosevelt inaugurated president. Advent of New Deal politics.

33. 1934 - Art as Experience is published. Dewey dedicates the book to Alfred Barnes. Dewey's thirteen year old grandson dies.

34. 1935 - The John Dewey Society is founded, dedicated to the study of school and society. Dewey publishes Liberalism and Social Action, a product of a series of lectures given at the University of Virginia.

35. 1937 - Dewey endorsed the Neutrality Act thinking that war would delay his social programs.

36. 1937 - Leon Trotsky charged with sedition against Stalin. In exile, Trotsky requested an impartial hearing and the American Committee for the defense of Leon Trotsky was formed. Dewey presided over the hearing as Honorary Chairman.

37. 1939 - Dr. Tsume-ch Yu, Chinese Consul General bestowed upon Dewey and Nicholas Murray Butler of Columbia the decoration of the Order of the Jade.

38. 1939 - Dewey changes his mind on the war and realizes that totalitarianism was a grave threat to the survival of democratic institutions in Europe. He publishes, "Higher Learning and the War" (American Association of University Professors Bulletin (Dec, 1939).

39. 1940 - Dewey, joined by Alfred North Whitehead, William P. Montague, and Curt John Ducasse, defended the scholarship of Bertrand Russell in New York City.

40. 1941 - The United States enters WWII after the Japanese attack on Pearl Harbor. 
41. 1945 - 1948 - Dewey works with Arthur F. Bentley on a cooperative venture resulting in a number of articles published in the "Journal of Philosophy."

42. 1945 - On August 6th and 9th, atomic bombs are dropped on Hiroshima and Nagasaki by the United States.

43. 1949 - Dewey's 90th birthday. Press releases from Canada, England, France, Holland, Denmark, Sweden, Israel, Mexico, Turkey, Japan, and India were sent to Dewey for his ninetieth birthday. Tributes to Dewey in the United States were extensive.

44. 1949 - The Soviet Union tests its first atomic bomb. William Faulkner wins the Nobel Prize for literature.

45. 1952 - Dewey dies of pneumonia at his apartment in New York City on June 1, 1952. Dewey cremated at Fresh Pond Crematory, Middle Village, Queens, NY.

46. 1952 - Sidney Hook publishes Some Memories of John Dewey.

47. 1965 - Official United States Dewey Stamp released commemorating the life and works of John Dewey.w

\section{ACADEMIC AWARDS}

- 1943: Copernican Citation

- 1946: Doctor "honoris causa" - University of Oslo

- 1946: Doctor "honoris causa" - University of Pennsylvania

- 1951: Doctor "honoris causa" - Yale University

- 1951: Doctor "honoris causa" - University of Rome

\section{REFERENCE}

1. Dewey, J. (1897). My Pedagogic Creed. School Journal, 54, 77-80.

2. Hickman, P. (2000). John Dewey. Muskingum College, Department of Psychology. Found online at http://www.muskingum.edu/ psych/psycweb/history/dewey.htm

3. Martin, Jay. (2003). The Education of John Dewey. Columbia University Press.

4. Neill, J. (2005). John Dewey, the Modern Father of Experiential Education. Wilderdom.com

5. The Center for Dewey Studies, Southern Illinois University Carbondale, http://deweycenter.siu.edu/about_bio.html 